\title{
Multatuli in Zombieland
}

\author{
PHILIP VERMOORTEL \\ University of Leuven \\ Onderzoeksgroep Literatuur en Cultuur \\ KU Leuven - Campus Brussel \\ Warmoesberg 26 \\ 1000 Brussel, Belgium \\ philip.vermoorte@@gmail.com
}

\section{Multatuli in Zombieland}

\begin{abstract}
In 1860, the Dutch author Multatuli (pen name of Eduard Douwes Dekker) published Max Havelaar, which was to become the most famous nineteenth-century Dutch novel. In 2016, the book was rewritten by Martijn Adelmund as a book in which also zombies play a role. By doing so, Adelmund follows a fifteen-year-old American literary tradition to rewrite literary masterpieces as zombie books. Since Max Havelaar neither contains many characters nor descriptions of Indonesian nature and has a rather simple plot, Adelmund decided to mix the book with another nineteenth-century Dutch literary masterpiece: Louis Couperus' De stille kracht. The purpose is to make secondary school pupils read the original Max Havelaar again and encourage them to compare the two versions in order to develop a critical understanding of Dutch colonial history and its present-day consequences. The review focuses on the way Adelmund combined the two classic books, reshaped the plot and added parts of his own. Attention is paid to the way in which the original language was modernized and to the question whether this book really can or will help young students to read the original. However noble Adelmund's objectives may be, it is very improbable that he will manage to realize them since the quality of the novel he created leaves a lot to be desired.
\end{abstract}

Keywords: Max Havelaar; Multatuli; adaptation; rewriting; Dutch literature; zombies; De stille kracht; Louis Couperus; Dutch colonialism 


\section{Quirk Books}

Zes jaar na de hertaling van Max Havelaar door Gijsbert van Es (Multatuli 2014) is er nu ook een Max Havelaar met zombies. De bewerker is Martijn Adelmund. Hij is uitgever van fantasy-boeken en heeft drie jeugdromans geschreven. Dit is zijn eerste roman voor volwassenen. ${ }^{1}$

Dat een gecanoniseerd meesterwerk omgebouwd wordt tot zombieliteratuur is, voor zover ik weet, een primeur in het Nederlandse taalgebied, maar in Amerika is het intussen al bijna een traditie. Vijftien jaar geleden werd in Philadelphia de uitgeverij Quirk Books opgericht,

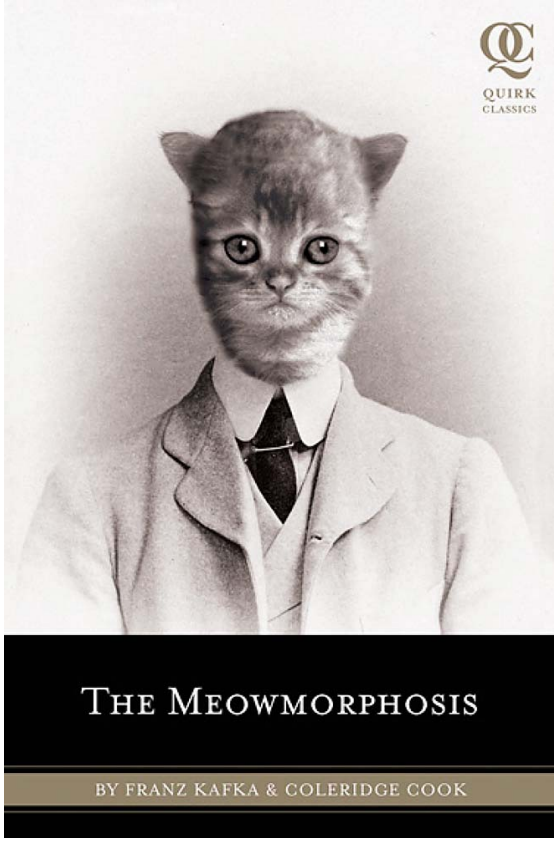

Figuur 1. Franz Kafka \& Coleridge Cook. 2011. The Meowmorphosis. Philadelphia: Quirk Books die nagenoeg uitsluitend maffe en griezelige - "quirk" betekent "eigenaardig trekje" - bewerkingen uitbrengt van gecanoniseerde romans. De catalogus biedt bijvoorbeeld Sense and Sensibility and Sea Monsters (2009) aan en Pride and Prejudice and Zombies (2015) naar Jane Austen. In The Meowmorphosis (2011) naar Franz Kafka verandert de held in "a man-sized baby kitten." Er bestaat zelfs een cyberversie van Lev Tolstoj onder de titel $A n^{-}$ droid Karenina (2010) alsook een William Shakespeare's Star Wars Trilogy (2014). En die boeken worden gretig gekocht en gelezen.

Maar Martijn Adelmund heult naar eigen zeggen niet zomaar mee met een modetrend. Zijn doel is verhevener. Hij wil dat scholieren Max Havelaar opnieuw gaan lezen en dat bovendien graag doen. Zijn zombieversie moet daartoe

\footnotetext{
${ }^{1}$ In de "Verantwoording" bij Max Havelaar met zombies vermeldt Martijn Adelmund op bladzijde 317 dat hij gebruik heeft gemaakt van de vijfde druk van Max Havelaar uit 1881 die in de universiteitsbibliotheek van Leiden berust onder signatuur S. Ned. 64 5531. Dat blijkt eigenlijk het eerste deel te zijn (Tekst) van de monumentale historisch-kritische uitgave die Annemarie Kets-Vree heeft verzorgd (Multatuli 1992). Voor De stille kracht heeft Adelmund gebruikgemaakt van de eerste druk uit 1900 in twee delen (Couperus 1900). Om de versie van Adelmund te vergelijken met die van Multatuli en Couperus hebben we in deze bijdrage eveneens die uitgaven gebruikt. Verwijzingen naar pagina's uit de zombiebewerking worden voorafgegaan door de "Z" van "zombie," verwijzingen naar Max Havelaar en naar de twee delen van De stille kracht krijgen respectievelijk "MH," "DSK1" en "DSK2" voor het paginanummer. "MH" verwijst daarbij uiteraard naar het eerste deel (Tekst) van de uitgave van Kets-Vree.
} 
de smaakmaker zijn, de opstap, de voor jongeren vertrouwde toegangspoort. Hij hoopt voorts "dat de scholieren dit boek lezen naast het origineel en nadenken over ons koloniale verleden en wat de gevolgen daarvan zijn in het heden" (Z: 303).

In het "Naschrift van de bewerker" (Z: 299-306) legt Adelmund verder ook nog uit dat de zombiefilm Night of the Living Dead van George A. Romero uit 1968 meteen opgevat werd als een politiek statement over de Amerikaanse samenleving en daaruit concludeert hij dat "de kritische Max Havelaar (1860) en het zombiethema voor elkaar gemaakt" (Z: 301) lijken. Het komt erop neer Multatuli's meesterwerk niet langer te behandelen als het "braaf heilig huisje" dat het geworden is, maar als de "sensatiegerichte aanklacht" (Z: 305) die het is geweest. En daar zijn zombies voor nodig want die zorgen in elk geval voor sensatie en via de parallel met Romero ook voor aanklacht.

Veel intrige heeft Max Havelaar niet. Er treden ook maar weinig personages in op en het zijn - op Droogstoppel en zijn omgeving na - in hoofdzaak ambtenaren. Natuurbeschrijvingen ontbreken bijna helemaal. Om die lacunes te vullen heeft Adelmund er niet beter op gevonden dan Max Havelaar te mixen met dat andere monument: De stille kracht van Louis Couperus uit 1900. In de "Proloog" maakt Adelmund de lezer wijs dat hij in 2009 het echte, originele handschrift van Max Havelaar in handen heeft gekregen. Droogstoppel heeft er in 1860 de zombiepassages uit weggelaten en Couperus moet het vast en zeker ingezien hebben want er komt veel van terug in De stille kracht. En anno 2016, wordt, dankzij Martijn Adelmund, de Havelaar eindelijk uitgegeven zoals Multatuli hem heeft bedacht, met zombies en al.

\section{Zombies}

Wie en wat die zombies zijn, komt de lezer in stukken en brokken te weten. De dukuns - lokale priesters - zijn in staat om doden weer tot leven te wekken en doen dat tot grote tevredenheid van de Nederlandse overheid. Want terwijl de dagwerkers slapen, bewerken de levende doden 's nachts het land en zorgen dus voor meer opbrengst, en daar is het de Nederlandse bezetter natuurlijk om te doen (Z: 127). Maar in 1849 breekt in Nederland de cholera uit en dat maakt de zombies agressief, moordzuchtig en onhandelbaar (Z: 128). Zo samengevat klinkt het misschien allemaal duidelijk, maar dat is het in het boek van Adelmund allerminst want er is van alles dat niet klopt. Hoe kan bijvoorbeeld de cholera die in 1849 uitbreekt in Nederland - een historisch feit - ervoor zorgen dat de "slaperziekte" zich voor het eerst manifesteert op het eiland Bali zoals we op bladzijde 27 te lezen krijgen? Op bladzijde 15 blijkt dan weer dat niet alleen de door de dukuns tot leven gewekte doden slachtoffer kunnen worden, maar 
ook alle levenden. Op bladzijde 47 wordt ons verzekerd dat "individuele slapers" niet gevaarlijk zijn, maar dat pas worden wanneer ze een "horde" vormen. Niettemin wordt Frits Droogstoppel door zo'n "individuele slaper" doodgebeten (Z: 25), slaan Saïdjah en zijn vrienden op de vlucht als ze één enkele zombie zien aankomen (Z: 196), wordt Saïdjah aangevallen door de "individuele" Adinda (die ook slaper geworden is) (Z: 227), en Havelaar door Slotering (die ook tot de zombies toegetreden is) (Z: 268), terwijl Droogstoppel op het einde dan toch weer niet aangevallen wordt door Sjaalman (die natuurlijk ook zombie geworden is) (Z: 297). En wat moeten we ons voorstellen bij de mededeling dat wie een paar "slapelozen" nodig heeft in zijn huishouden, ze ook kan "kweken" (Z: 122)? Adelmund maakt het allemaal nog bonter door al wat hem al schrijvend te binnen schiet, er gaandeweg bij te plakken. Op bladzijde 173 zijn de agressieve slapers plotseling "een teken van Allah" tegen de westerse bezetter, maar zeven bladzijden verder blijken het de poyangs of kwade geesten te zijn die - eveneens uit afkeer van het westen - de agressie van de slapers opgewekt hebben. Op bladzijde 268 leren we dan weer dat je ook door vergiftiging slaper kunt worden. Dat van die cholera is Adelmund dan al lang vergeten.

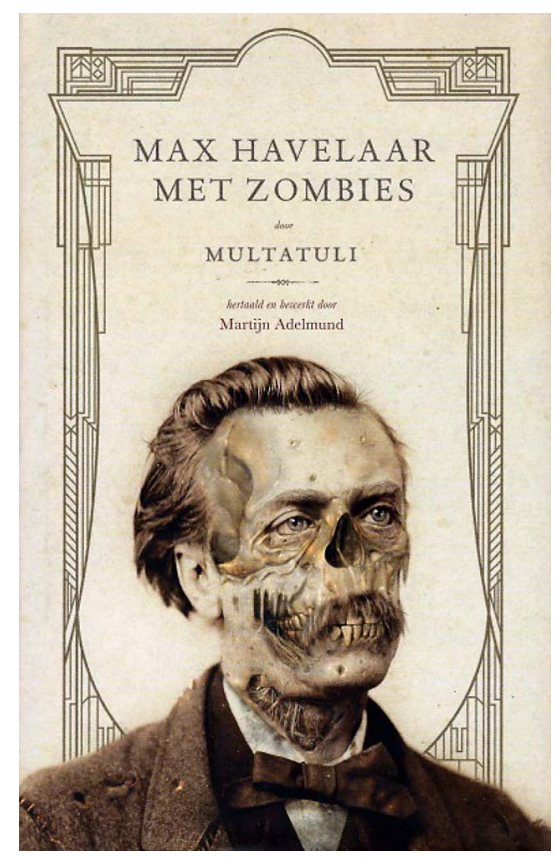

Figuur 2. Multatuli. 2016. Max Havelaar met zombies, hertaald en bewerkt door Martijn Adelmund. Amsterdam: Luitingh-Sijthoff
De verwarring wordt nog groter naarmate we te weten komen wat die zombies nu eigenlijk allemaal kunnen aanrichten en hoe ze bestreden kunnen worden. "Een paar knallen," zo wordt ons op bladzijde 51 verzekerd, "en de eerste slapers waren gevallen." Ze spartelen dan wel nog een beetje, maar na het genadeschot is het er definitief mee afgelopen. Het volstaat zelfs om ze een stevige trap te geven "om één, twee, drie hoofden achtereenvolgens te verpulveren" (Z: 110). In zijn "Rede tot de hoofden van Lebak" (Z: 114-122), verzekert Havelaar dan ook dat de overheid "de wapens [heeft] om de slapers te bevechten, en goede krijgers" (Z: 116). Je vraagt je af waarom ze die slapers dan niet gewoon een voor een neerknallen, maar dat mag natuurlijk niet want dan hadden we nu geen zombieboek in handen. En dus wordt er verteld dat er (nutteloze) barricades opgeworpen worden tegen de zombies (Z: 46) en dat de enige verdediging van 
het dorp Badur Baru een (al even nutteloze) greppel is (Z: 217). En dus loopt iedereen, ook als goed en wel geweten is dat groepen slapers voor de poort staan, lekker ongewapend rond en moet finaal zijn toevlucht nemen tot speren en drietanden. En dus moeten de zombies opeens, om heel echt dood te zijn, ook nog eens in mootjes worden gehakt (Z: 109) of moet je ze, zoals we op bladzijde 111 vernemen, "een scherp staal door oogkas, slaap of schedelbasis" steken want je moet "de hersenen zien te raken." Er is, kortom, werkelijk niet wijs uit te raken.

Helemaal te gek wordt het wanneer Adelmund die zombies ook nog een rol wil geven in de strijd die Havelaar, net als in het originele verhaal, voert tegen de misbruiken door de lokale hoofden. De Nederlandse regering stelt, zoals gezegd, de slapers aanvankelijk te werk als nachtpersoneel, maar wanneer vanaf 1850 de slaperziekte zich steeds sneller uitbreidt, wordt een verbod uitgevaardigd op het houden van slapers. De corrupte regent - het inlandse hoofd - heeft echter wel nog slapers in dienst en stuurt ze zelfs uit om de lokale bevolking te plunderen (Z: 137). Wie het misbruik wil uitroeien, hoeft dus maar die clandestiene slapers uit te schakelen. Niettemin zegt Havelaar tot controleur Verbrugge "ik denk dat we de slapers in Lebak kunnen uitroeien. Maar dat kan alleen als de bevolking niet langer wordt uitgezogen" (Z: 138). Begrijpe wie begrijpen kan.

\section{Mix}

Tot zover over de zombies. Laten we nu eens kijken naar wat in deze versie overeind is gebleven van de originele werken van Multatuli en Couperus en hoe Adelmund dat heeft gemixt en voorzien van eigen bijvoegsels.

In Max Havelaar met zombies is de verhaallijn van Multatuli's origineel grotendeels behouden, al zijn nogal wat stukken op een andere (en niet betere) plaats terechtgekomen en al is het geheel drastisch ingekort. Toch zijn heel wat weliswaar beroemde delen uit Multatuli's roman nagenoeg integraal overgenomen en dat is verwonderlijk omdat ze dikwijls nogal lang uitvallen en dus misschien toch niet zo geschikt zijn om de jonge lezer van vandaag te boeien, wat toch de bedoeling was. Het begint al met het "Onuitgegeven toneelspel" (Z: 17-18), dat bovendien op zo'n manier bewerkt is dat de pointe volkomen de mist ingaat. Bij Multatuli (MH: 2) eindigt het verhoor ermee dat de onschuldige Lothario toch moet hangen omdat hij schuldig is aan eigenwaan. Bij Adelmund wordt hij veroordeeld omdat hij de rechtsgang belemmerd heeft, waardoor van de Multatuliaanse aanklacht tegen de absurde rechtslogica niets overeind blijft. Ook het beroemde "Zelfportret van Havelaar" (MH: 57-59) is in zijn geheel overgenomen, maar om onbegrijpelijke redenen in tweeën geknipt. Het eerste stuk krijgen we op bladzijde 55 te lezen, het tweede 31 bladzijden verder. De stilistische schwung 
ervan is compleet onderuitgehaald en hier en daar zijn een paar flauwe zinnen toegevoegd over Havelaar als zombiedoder. Nog verbazender is dat het "Pak van Sjaalman" (MH: 22-27) integraal opgenomen is. Enkel de zesde en de eenentwintigste titel zijn vervangen door titels die verband houden met zombies en merkwaardig genoeg zijn alle toevoegingen waarin Droogstoppel zegt dat hij een stuk uit het pak kan gebruiken voor zijn boek, geschrapt of verkort tot "Ik heb het apart gelegd." Het "Pak van Sjaalman" beslaat in deze zombieversie zeseneenhalve bladzijde (Z: 35-41) en wordt al halverwege het tweede hoofdstuk opgediend. Of de jonge lezer hierdoor verleid zal worden om verder te lezen, valt zeer te betwijfelen. Verwonderlijk is ook dat een deel van Droogstoppels kritiek op het gedicht van Heine waar Stern zo vol van is, een plaats krijgt (Z: 59-61). Zelfs de "Rede tot de hoofden van Lebak" is nagenoeg volledig behouden (Z: 114-122), al wordt ze niet uitgesproken bij de installatie van Havelaar als assistent-resident, maar bij de begrafenis van Eva Verbrugge, nadat die door de slapers half opgepeuzeld is. Adelmund probeert de thematiek van de "Rede tot de hoofden van Lebak" om te buigen naar de strijd tegen de slapers, maar dat lukt, zoals hierboven al werd vastgesteld, maar half. Ook de evergreen "De Japanse steenhouwer" (MH: 117-119) krijgt een plaats tussen de zombies (Z: 167-169), maar wordt verteld door de regent en niet door Havelaar, en wel als kritiek op de hebzucht van de westerling (Z: 170), al ligt die interpretatie toch niet echt voor de hand.

Zoals gezegd heeft Adelmund Multatuli's boek gemixt met Couperus' De stille kracht. Het is een koud kunstje om de Couperuspassages eruit te filteren. Telkens wanneer de natuur wordt beschreven of wanneer er gefilosofeerd wordt over de Nederlandse aanwezigheid in Nederlands-Indië en het ondoorgrondelijke van de inlander, is Couperus aan het woord. De openingsbladzijde van Couperus' meesterlijke roman is ook die van Adelmunds derde hoofdstuk. Voorts herkennen we onder meer de tafeldansscène, de scène waarin Léonie geesten hoort huilen in de bomen en de gokverslaving van de familie van de regent.

Adelmund heeft aan Tine, de vrouw van Havelaar, het karakter gegeven van Couperus' Eva Eldersma en aan mevrouw Slotering het nymfomane van Léonie van Oudijck, inclusief een stiefzoon waarmee ze lekker sekst. Secretaris Onno Eldersma is in de zombieversie controleur Onno Verbrugge geworden en een aantal personages uit Couperus' roman is gewoon overgenomen teneinde wat meer niet-ambtenarenvolk te hebben dan in Multatuli's origineel. Ten slotte zijn er de passages waarin Adelmund de mix aan elkaar lijmt met inlassingen van eigen hand. Merkwaardig daarbij is dat hij twee bladzijden lang 38 soorten Javaanse geesten opsomt die verder geen enkele rol spelen in zijn verhaal (Z: 181-183) en op bladzijde 180 zeven onvertaalde Maleise (?) manieren om poyangs te aanroepen die evenmin van enig belang blijken. Alweer rijst de vraag of dat jongeren 
ertoe zal aanzetten om eerst dit zombieboek en vervolgens dan ook nog de echte Havelaar te lezen en zo tot een kritische analyse van het Nederlandse koloniale verleden te komen.

Tussen Multatuli's boek en dat van Couperus ligt veertig jaar en tussen Couperus en Adelmund meer dan honderd. Bovendien gaapt er een onoverbrugbaar verschil in stijl tussen de nuchtere Multatuli en de barokke Couperus. Om die twee stijlen met elkaar en met zijn eigen manier van schrijven te verzoenen, restte Adelmund geen ander alternatief dan Multatuli en Couperus te ontdoen van alles wat hen tot Multatuli en Couperus maakt. Laten we even nagaan hoe hij dat doet.

\section{Stijl: Multatuli}

Adelmund laat zijn boek voorafgaan door het volgende citaat uit Max Havelaar (MH: 134) "Als ge niet getroffen zyt door de stomme akeligheid van een lyk dat daar ligt, er is plaats in myn verhaal voor een slachtoffer dat nog stuiptrekt en gilt!" Bij Adelmund wordt dat "Als u niet geraakt wordt door afschuw van de vondst van een lijk, dan is er in mijn verhaal nog plaats voor een slachtoffer dat stuiptrekt en gilt" (Z: 5). Die hertaling geeft meteen al een idee van de grove borstel waarmee Adelmund door het origineel gaat. Het krachtige "de stomme akeligheid van een lyk" verwordt tot het bloedeloze "afschuw van de vondst van een lijk." Is "geraakt" beter dan "getroffen"? En waarom moest "nog" van plaats wisselen? Het citaat wordt in de hertaling zelf (Z: 105) bovendien volledig uit zijn context gerukt. Multatuli drijft de spot met de trukendoos van de romantiek en schetst een karikatuur van de romantische schrijver. Bij Adelmund wordt Multatuli's ironie een aansporing om zombies in zijn verhaal te introduceren.

Het "Pak van Sjaalman" dat Adelmund ons presenteert (Z: 35-41), leert ons veel over de manier waarop hij het hele boek bewerkt en hertaald heeft. "Horror vacui" vervangt hij door "afschuw van de leegte," maar "perpetuum

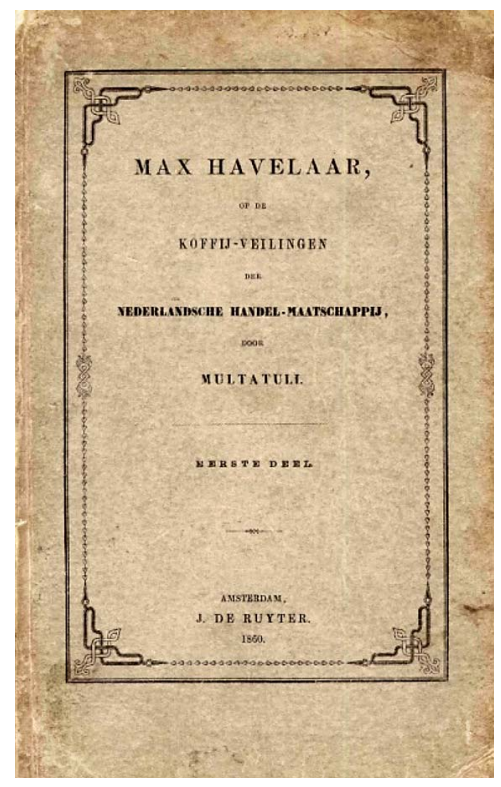

Figuur 3. Multatuli. 1860. Max Havelaar of de koffij-veilingen der Nederlandsche Handel-maatschappij. 1 ed. Amsterdam: J. de Ruyter 
mobile," "ius primi occupantis" en "ius talonis" laat hij staan. In het eigenlijke verhaal vervangt hij Multatuli's "hy schwärmt" (MH: 21) door "hij [is] een romanticus" (Z: 34), maar in het "Pak van Sjaalman" laat hij "gemüthlichkeit," "empfindelei" en "sensiblerie" gewoon staan. Hij verwijdert wél Multatuli's " $h$ " uit het eerste woord omdat die in het hedendaagse Duits niet meer geschreven wordt, geeft het woord een hoofdletter en zet het cursief, maar in het tweede Duitse woord laat hij Multatuli's kleine letter staan en gebruikt geen cursief, evenmin voor "sensiblerie." "Hydraulisch" wordt "waterkundig," "makelaars" wordt "tussenhandel," "pedanterie" wordt "aanstellerij," "galanterie" wordt "hoffelijkheid" en "mathematisch" wordt "wiskundig," maar "cellulair," "Civiele Rechtsvordering," "successierecht," "piëtisterij," "rapsoden," "apocrief" en "efelkustiek" blijven staan. Soms is Multatuli's stijl zo sterk dat zelfs Adelmund er niet aan kan weerstaan. Hij heeft het bijvoorbeeld net als Multatuli over "het boek van Job" terwijl die "van" tegenwoordig veelal weggelaten wordt, en twee keer behoudt hij Multatuli's "wezen" waar we tegenwoordig "zijn” zouden schrijven. De naam van de Franse liedjesschrijver Pierre-Jean de Béranger wordt vervangen door "het Franse chanson," maar die van de tegenwoordig al even onbekende August Lafontaine blijft staan. En zou de naam "Orsini” de jonge lezer van nu nog iets zeggen? Soms zit de hertaler er compleet naast. Het lidwoord "der" wordt een paar keer foutief omgezet naar "van" in plaats van "van de" met als resultaat hertalingen als "Over de oorzaken van de opstand van Nederlanders tegen Spanje" of "Over de schoonheid van vrouwen in Nîmes en Arles." Multatuli's "Over het tegennatuurlyke van School-Inrichtingen" wordt "Over het tegennatuurlijke van schoolmeubilair," "omdat hy zo op waarheid aandringt" wordt "als hij zo van de waarheid houdt," "epidemisch" wordt "ziekelijk" en "Over de kracht der dwaling" wordt "Over de voordelen van verdwalen." In "Over de werkeloosheid van een Opperwezen, by volmaakte natuurwetten" vervangt Adelmund "werkeloosheid" door "werkloosheid," wat iets heel anders is, maar wanneer hij op 113 een zin van eigen makelij inlast, gebruikt hij zelf "werkeloos."

De hertaling roept ook allerlei fouten in het leven. Multatuli schrijft "hy scheen daarmee zeker plan te hebben" (MH: 27) en dat wordt bij Adelmund "hij scheen daarmee zeker plannen te hebben" (Z: 42), wat iets heel anders betekent. Multatuli schrijft even verder "Hem het pak terugzenden, kon ik niet, want ik wist niet waar hy woonde. Het was nu eenmaal open" (MH: 27). Adelmund vervangt "pak" door "bundeling" - de meerwaarde daarvan ontgaat mij volkomen - maar vergeet in het tweede zinnetje het genus aan te passen (Z: 42). Multatuli gaat verder met "Ik kon niet loochenen dat ik 't had ingezien, en dit zou ik ook niet gedaan hebben, omdat ik zoo van de waarheid houd." Dat wordt in de hertaling "Ik kon niet doen alsof ik er niet naar had gekeken, en dat zou ik ook niet willen, omdat ik zo van de waarheid hou." Je kunt je afvragen of "loochenen" te moeilijk 
is voor de scholier van vandaag en of "naar iets kijken" hetzelfde betekent als "iets inzien," maar erger is dat de werkwoordstijden niet meer kloppen. Er had moeten staan "gewild hebben" (zoals bij Multatuli) en niet "willen." De volgende zin bij Multatuli luidt "Ook gelukte't me niet het weer zóó te sluiten dat er van 't openen niets blyken kon." Dat krachtige oxymoron verdwijnt volkomen in "Ook lukte het me niet het pak" - nu dus toch weer "pak" in plaats van "bundeling" - "weer zo te sluiten dat het leek alsof er niemand aan had gezeten." Multatuli gaat verder met "Bovendien mag ik niet ontveinzen dat [...]" en dat wordt in de zombieversie "Bovendien moest ik toch echt bekennen dat [...]" waarin alweer de foute tijd is gebruikt want Multatuli laat Droogstoppel hier rechtstreeks tot de lezer spreken. Multatuli schrijft drie bladzijden verder "Eén ding staat vast: de bouwstoffen die ik in Sjaalman's pak gevonden had, waren belangryk voor de makelaars in koffi" (MH: 29). Adelmund acht het nodig om daar twee zinnen van te maken en alweer kiest hij de verkeerde tijd: "Eén ding staat vast: de notities die ik in Sjaalmans pak papier gevonden had, waren belangrijk. Ze zijn in elk geval belangrijk voor iedereen die in koffie handelt" (Z: 42). Nog afgezien van de sprong van "waren" naar "zijn," is de vraag wat de toegevoegde waarde is van "pak papier" in plaats van "pak."

De voorbeelden uit bovenstaande alinea komen allemaal uit twee willekeurig gekozen pagina's. Men kan zich op grond daarvan en op basis van de korte analyse van het "Pak van Sjaalman" stilaan wel een idee vormen van de vele fouten waartoe deze hertaling leidt. Ik som de belangrijkste hieronder nog even op en geef wat extra voorbeelden.

Een eerste soort fouten vormen die hertalingen die de betekenis van het origineel wijzigen. Twee voorbeelden. "Er zyn menschen die altyd klagen" (MH: 180) wordt hertaald tot "Er zijn altijd wel mensen die klagen" (Z: 205). "Met tranen van gevoel op de wangen" (MH: 182) wordt "Met tranen op de wangen van ge-

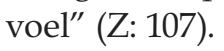

Ten tweede zijn er hertalingen die de oorspronkelijke betekenis vertroebelen of zelfs onbegrijpelijk maken. Wawelaar zegt over de inlandse heidenen dat zij zich schandelijk onderwerpen aan "het juk van eigenbelangzuchtige priesters" (MH: 98) en doelt daarmee op de lokale religieuze leiders. Adelmund vervangt de laatste twee woorden door het abstracte "eigenbelang" (Z: 184), waardoor volstrekt onduidelijk wordt op wie de uitval van Wawelaar betrekking heeft.

Adelmunds hertaling leidt ook tot verlies aan zeggingskracht. Multatuli schrijft "Dan vond ik nog uittreksels uit dagboeken, aanteekeningen en losse gedachten... sommigen werkelyk heel los" (MH: 27). Adelmund vervangt het laatste woord door "onsamenhangend," waardoor het woordenspel met "los" verloren gaat. Multatuli schrijft "Maar hierin lag juist de fynheid van den strik, dien ik hem spande" (MH: 143). Dat wordt bij Adelmund "Maar hierin lag juist 
de subtiliteit van de valstrik die ik aanlegde" (Z: 59). Multatuli schrijft "[om] de fyne trekken te penseelen die er staan in den kelk eener lelie" (MH: 134). Dat wordt "[om] de fijne penseeltrekjes die nodig zijn om de kelk van een lelie weer te geven" (Z: 105), waardoor niet alleen de stilistische kracht verloren gaat, maar waardoor ook de betekenis verandert, want bij Multatuli horen de fijne trekken bij de lelie en niet bij het penseel. Wanneer Saïdjah's buffel niet meer verder wil omdat hij weet dat een tijger op het punt staat aan te vallen, schrijft Multatuli krachtig "Het dier stond pal" (MH: 188). Dat wordt bij Adelmund verflauwd tot "Maar hij wilde niet echt bewegen" (Z: 195). Multatuli's "Ik weet niet of Saïdjah Adinda liefhad" (MH: 289) wordt - in de zombieversie heeft "Saïdjah" geen trema "Om heel eerlijk te zijn weet ik niet of Saidjah wel zoveel hield van Adinda" (Z: 258).

Een vierde reeks fouten valt onder de categorie "inconsequentie." Op bladzijde 292 vervangt Adelmund "lui, pedant en ziekelijk" (MH: 29) door "lui, opstandig en ziekelijk," maar op de bladzijden 210 en 211 laat hij het origineel (MH: 184 en MH: 185) ongemoeid. Het werkwoord "onderkruipen" wordt de ene keer hertaald als "een onderkruiper zijn" (Z: 27 - MH: 8), de andere keer als "zich verlagen" (Z: 34 - MH: 21). Multatuli schrijft "Ik had, zooals ik reeds zeide, eenige stukken ter-zy gelegd, omdat ze my toeschenen in myn vak te-pas te komen, en voor myn vak leef ik" (MH: 27). Adelmund vervangt "vak" twee keer door "werk" (Z: 42) terwijl hij - voor zover ik heb kunnen nagaan - overal elders "vak" gewoon "vak" laat zijn. Bovendien creëert hij daardoor verwarring tussen het vak van koffiemakelaar (zoals Multatuli het bedoelt) en het "werk" dat Droogstoppel zal laten schrijven.

In de "Rede tot de hoofden van Lebak" wordt de zin "Wys my de plaats waar ik gezaaid heb!" (MH: 81) - bovendien de titel van Multatuli's brochure uit 1861 - versimpeld tot "Waar is toch de plaats waar ik gezaaid heb?" (Z: 116), maar op dezelfde bladzijde blijft de archaïsche formulering "waar Hij [= Allah] Zijn zon doet gloeien ter verschroeiing" (MH: 116) gewoon staan. Vreemd is ook dat Adelmund het totaal in onbruik geraakte woord "knevelarij" - dat nu bovendien iets heel anders betekent dan in Multatuli's tijd - alleen op bladzijde 268 (MH: 207) vervangt door "de misdaden", maar op bladzijde 66 (MH: 69) en 122 (MH: 86) laat staan in tegenstelling tot bijvoorbeeld hertaler Gijsbert van Es, die het systematisch vervangt door "afpersing." ${ }^{2}$ Een andere vorm van inconsequentie is dat Javaanse woorden en uitdrukkingen soms cursief gedrukt worden en soms niet, en nu eens wel en dan weer niet worden vertaald.

Adelmund heeft ook wat moeite met het register. Wanneer Saïdjah zijn oude min terugziet, duiken opeens woorden op als "jongske" en "knuffel" (Z: 192).

${ }^{2}$ Zie Vermoortel (2016: 32). 
Droogstoppel, die erg trots is op zijn stand en zeer gesteld op etiquette, neemt in deze zombieversie woorden in de mond als "snapt u" (Z: 23) en "een maf gedicht" (Z: 230). Ook in de hertaalde "Rede tot de hoofden van Lebak" duiken uitdrukkingen op die er niet in thuishoren zoals "U weet vast dat" (Z: 114), "de vreugde zit 'm in het snijden van de rijstplant" (Z: 115), "Zeg eens eerlijk" (Z: 115) en "Nou dan" (Z: 122).

Een zesde en laatste reeks fouten zijn doodeenvoudig taalfouten. Wellicht onder invloed van Multatuli's "ge" worden "je" en " $\mathrm{u}$ " door elkaar gebruikt (Z: 107, Z: 259). Het meervoud van "gouverneur-generaal" is niet "gouverneursgeneraals" (Z: 287). Er worden fouten gemaakt tegen het genus zoals bijvoorbeeld in de volgende zin waarin het betrekkelijk voornaamwoord meegaat met "Europeanen," maar het werkwoord met "merendeel": "het merendeel van de Europeanen die met hem in aanraking kwam" (Z: 81). Er zijn fouten tegen het getal (Z: 15, Z: 183, Z: 243) en tegen de werkwoordstijden (Z: 83, Z: 180, Z: 207208, Z: 245, Z: 277). Sommige zinnen van Adelmund zelf klinken - althans in mijn oren - vreemd. Enkele voorbeelden. "Er is nu eenmaal een te belangrijk verband tussen de gebeurtenissen en wat mensen daarvan geloven, waardoor je de beschrijving van het tweede onmogelijk zou kunnen weglaten" (Z: 20), "zodat u [...] niet verontwaardigd zou zijn jegens de verkeerde persoon" (Z: 58 - ik cursiveer), "Iedereen moest ervan lachen" (Z: 103 - ik cursiveer), "Na verloop van tijd drong zich alleen een probleem op" (Z: 243), "kritiek tegen" (Z: 170) in plaats van "op," "liever houden van" (Z: 184) in plaats van "meer."

\section{Stijl: Couperus}

Nadat in de eerste twee hoofdstukken uit de zombieversie het leukste uit Max Havelaar ontdaan is van zoveel mogelijk Multatuliaanse trefzekerheid, vangt vanaf het derde hoofdstuk de bewerking aan van De stille kracht. Die vertoont dezelfde tekortkomingen als die welke we geconstateerd hebben in Max Havelaar, maar toch is er meer van Couperus overeind gebleven, wat begrijpelijk is omdat Couperus een zo afwijkende stijl heeft dat die bijna niet te neutraliseren valt. Ik beperk mij tot een paar voorbeelden, ook al omdat er minder te geven zijn aangezien het aandeel van Couperus' roman in Adelmunds zombieboek maar een vierde bedraagt van dat van Multatuli.

Adelmund begint, zoals vermeld, zijn derde hoofdstuk met de openingsbladzijde van De stille kracht. De eerste zin luidt bij Couperus "De volle maan, tragisch dien avond, was reeds vroeg, nog in den laatsten dagschemer opgerezen als een immense, bloedroze bol, vlamde als een zonsondergang laag achter de tamarindeboomen der Lange Laan en steeg, langzaam zich louterende van hare tragische 


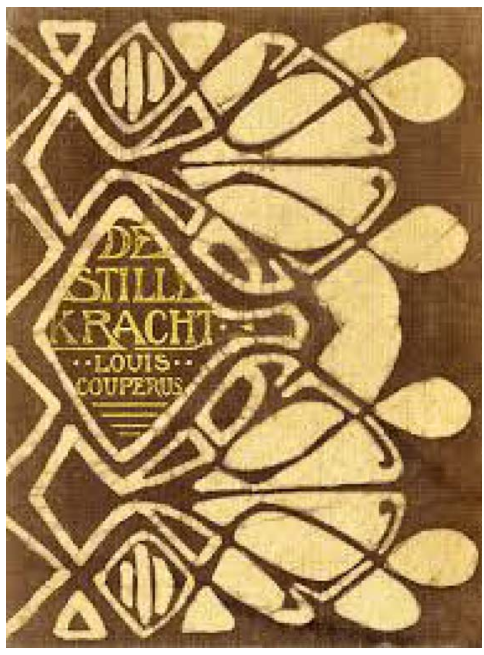

Figuur 4. Louis Couperus. 1900. De stille kracht. Amsterdam: Veen.

tint, in een vagen hemel op" (DSK1: 1). Daarvan blijft over "De volle maan was die avond al vroeg, nog in de laatste dagschemer, opgerezen als een immense bloedrode bol. Hij vlamde als een zonsondergang laag aan de horizon boven de rivier" (Z: 46). Van Couperus eigen stijl rest zo goed als niets en zelfs dat weinige blijft heel anders klinken dan de bewerkte taal van Multatuli en die van Adelmund zelf. Ik geef nog een ander voorbeeld waaruit hetzelfde blijkt. Couperus beschrijft Eva Eldersma als "Zij was klein, regelmatig molligjes; zij was heel blank, bleek-blank, met groote zwarte verwonderde oogen" (DSK1: 88). Dat wordt bij Adelmund "Ze was lelieblank, met grote zwarte verwonderde ogen" (Z: 90).

Meer nog dan bij Multatuli, kan Adelmund niet weerstaan aan de kracht van Couperus' taalmeesterschap. De typering van mevrouw Doorn de Bruijn als "een zware, placide, melancholieke vrouw" (Z: 90) neemt hij letterlijk over (DSK: 90), evenals die van Ida van Helderen "met haar grote ogen vol zwart fluwelen tragiek" (Z: 92 - DSK1: 92). Alleen de spelling is gemoderniseerd. Zelfs een zeldzaam woord als "kwispedoor" (Z: 94 - DSK1: 94) of een nieuwvorming als "huiverkil" (Z: 263 - DSK2: 100) zijn onveranderd overgenomen. Op bladzijde 91 krijgen we in de beschrijving van mevrouw Slotering de volgende regelrecht van Couperus gekopieerde typering te lezen "een rustig Juno-mooi, met de ogen van Venus" (DSK1: 92). Zou een scholier van nu zich daar iets bij kunnen voorstellen? Waarom zijn dergelijke woorden en zinnen blijven staan in een boek dat van Max Havelaar een versie voor de Twitter- en Facebookjongeren van vandaag wil maken? Het antwoord is, zoals gezegd, dat Couperus zo'n groot schrijver is dat ook een zombiehertaler voor zijn talent moet buigen. Adelmund introduceert zelfs Couperiaanse woorden uit ander werk zoals het reeds genoemde "lelieblank" (Z: 90) dat hij uit Fidessa gehaald kan hebben (Volledige Werken, deel 15: 17) en "goudglinsterend" (Z: 51) uit misschien De ongelukkige (Volledige werken, deel 36: 80).

Je krijgt finaal de indruk dat wie eenmaal aan het hertalen slaat, zich op den duur verplicht voelt om na elk paar zinnen hier en daar een woord te vervangen. "Murmelde" (DSK1: 103) wordt dan "mompelde" (Z: 102), "tikte voort" (DSK1: 104) wordt "tikte door" (Z: 103) "suggereeren" (DSK1: 107) wordt "opschrijven" (Z: 104), “ondervinding" (MH: 181) wordt "ervaren mening" (Z: 206) en "spaarpot" (MH: 183) wordt "leefgeld" (Z: 208). Waarom toch? 


\section{Verhaaltechniek}

Een verhaal vertellen is niet alleen een kwestie van taal en stijl, maar ook van structuur. Een romancier moet de gebeurtenissen zo logisch aan elkaar weten te binden dat de lezer alles goed kan volgen. Ook de introductie van nieuwe personages vergt meesterschap, zeker wanneer het gaat om een verhaal met veel personages. Bovendien moet de lezer via subtiele herhalingen en epitheta ornantia tijdens zijn lectuur op het juiste spoor gehouden worden.

Adelmund slaagt daar niet goed in. Een paar voorbeelden. Net als in Max Havelaar (MH: 10) denkt Droogstoppel in de zombieversie terug aan "parfumerieën" wanneer hij Sjaalman na veel jaren toevallig terugziet (Z: 29). Bij Multatuli klopt dat omdat Sjaalman Droogstoppel destijds gered heeft uit de klauwen van een boze Griek die "reukgoed" verkocht (MH: 11), maar bij Adelmund verkopen de Griek en zijn knappe dochter "kaartjes voor een exotisch rariteitenkabinet" (Z: 20) en daar komt geen "reukgoed" aan te pas. Op het einde van zijn boek brengt Adelmund de geur van de eerste ontmoeting in verband met de stank die Sjaalman al vanaf die eerste ontmoeting als zombie verspreidt (Z: 297). Maar hoe zou die stank, waarvan ons dit hele zombieboek door duidelijk wordt gemaakt dat het er een is van dood en verderf, herinneringen kunnen oproepen aan "reukgoed" en "parfumerieën"? Op bladzijde 20 zegt Droogstoppel dat hij veel te oud is om de Griekse kaartjesverkoopster mooi te vinden, maar een bladzijde verder vernemen we dat haar schoonheid hem helemaal in de war brengt. Op bladzijde 22 laat Adelmund Droogstoppel zeggen "En dat brengt me weer op de Westermarkt", maar in het voorgaande is niets te vinden dat hem weer op die markt zou kunnen brengen. Op bladzijde 51 is er opeens geluid te horen "van trappelende paardenhoeven," maar op de vorige bladzijden valt geen paard te bespeuren. Op bladzijde 90 wordt Ida van Helderen als volgt geïntroduceerd "Ze bleek mevrouw Van Helderen te heten en was de vrouw van de secretaris." Alleen hebben we op dat moment nog geen secretaris gehoord of gezien. Léonie Slotering heeft, net als Léonie van Oudijck bij Couperus, veel minnaars (DSK1: 91), maar haar gedrag is in Adelmunds verhaal niet meer dan een fait divers. Op bladzijde 92 heet Van Helderen nog Frans, zoals bij Couperus, maar op 106 is zijn voornaam Frits geworden. Op bladzijde 93 lezen we dat de regent en zijn familie al wat ze bezaten verdobbeld hebben en daardoor "allang niet rijk meer" zijn, maar op 161 vernemen we dat dat komt "door de laatste suikercrisis." Eva Eldersma zegt in De stille kracht in een van haar neerslachtige buien "Ik vind die bruine gezichten van mijn jongens in eens griezelig om me" (DSK1: 97) en denkt daarbij aan haar Indonesische bedienden. Adelmund legt die woorden in de mond van de vrouw van Havelaar en dat wordt dan "Als ik in een neerslachtige bui ben, vind ik dat bruine gezicht van mijn kleine Max ineens griezelig" (Z: 95). Maar hoe zou Max, 
het zoontje van twee blanke Hollanders, aan een bruin gezicht kunnen komen? Op bladzijde 118 is een fossiel stuk uit de oorspronkelijke Max Havelaar blijven staan over Raden Wiera Kusuma (MH: 84), maar die speelt verder geen enkele rol in de zombieversie. Op bladzijde 157 zegt Havelaar tot Saïdjah "u heeft ons goed geholpen," terwijl hij nog helemaal niets gedaan heeft. Op bladzijde 159 vernemen we dat de resident zijn huis heeft gebouwd tegen een suikerfabriek, maar twee bladzijden verder blijkt het om de woning van de regent te gaan en op bladzijde 170 is het toch weer die van de resident. Adelmund laat Saïdjah zelf zijn beroemde "eentonige" verhaal vertellen (MH: 186-205), maar vergeet op bladzijde 214 Saïdjah te vervangen door "ik." Op 220 beleven we de zonsopgang op de dag dat Saïdjah Adinda zal terugzien. Niettemin vraagt Adinda hem vijf bladzijden verder waarom hij zo laat nog buiten rondloopt en blijken Duclari en zijn mannen - nadat intussen enige tijd verstreken is - nog lampen nodig te hebben om Havelaar te vinden (Z: 228). Op 227 deelt de verteller ons over Saïdjah mee "De Javaan prevelde een paar korte gebeden," terwijl we zeven bladzijden vroeger vernomen hadden "De Javaan had niet geleerd te bidden." Op 229 wordt Havelaar door Duclari gered maar daar had Verbrugge moeten opduiken, want Duclari is in Rangkasbitung gebleven. Op 230 laat Adelmund Droogstoppel zeggen "Wat was dat voor een maf gedicht over iemand die nog horen kan als hij dood is?" en refereert daarmee natuurlijk aan het beroemde "Ik weet niet waar ik sterven zal" (MH: 192-193). Alleen komt dat gedicht in de zombieversie niet voor.

Het zogenaamde toneelstuk dat tijdens een benefietavond in Rangkasbitung opgevoerd wordt (Z: 251-256), is bedoeld als hoogtepunt van de zombie-Havelaar. Het is echter helemaal geen toneelstuk, maar een opeenvolging van taaie monologen die geen enkele artistieke en al zeker geen theatrale waarde hebben. Dat de opvoering ervan, zoals ons in de volgende bladzijden verzekerd wordt, een succes is geweest, is volstrekt ongeloofwaardig.

\section{Feiten}

Adelmund heeft zo te zien ook enigszins uit het oog verloren dat zijn boek zich afspeelt op het einde van de jaren vijftig van de $19^{\text {de }}$ eeuw en dat hij, zeker bij de mix met een boek uit 1900, op zijn hoede had moeten zijn voor anachronismen.

In de oorspronkelijke Max Havelaar komt de nieuwe assistent-resident aan in een rijtuig, bij Adelmund arriveert hij in 1855 per trein in het station van Pandeglang (Z: 50). De Nederlands-Indische Spoorweg Maatschappij (NIS of NISM) is echter pas opgericht op 27 augustus 1863 en dus lijkt het mij - maar een specialist ben ik niet - erg onwaarschijnlijk dat al tien jaar eerder een station zou 
hebben gefunctioneerd in een gebied dat bovendien niet bepaald tot het centrum van Java behoorde. Dezelfde bedenking geldt uiteraard voor het treinstation in Pising op bladzijde 215. Tine, de vrouw van Multatuli, beheerst in Adelmunds zombie-Havelaar de gevechtssport pencak (Z: 107, Z: 109, Z: 111 en Z: 236), waarvoor twee drietandige steekmessen nodig zijn, zogenaamde sai (Z: 69), die ze dan ook altijd bij zich heeft. Kan een lezer met enig historisch bewustzijn zich voorstellen dat een vrouw van een Nederlands koloniaal ambtenaar anno 1860 een gevechtssport zou hebben beoefend en daartoe onder haar rokken permanent twee drietanden verborgen zou hebben gehouden? Op bladzijde 147 speelt Tine voor haar man "uit Wagners Parsifal," net als Eva uit De stille kracht. Alleen is Adelmund vergeten dat Wagner pas in 1878 klaar was met het eerste bedrijf en dat de opera voor het eerst opgevoerd is in 1882.

\section{Conclusie}

Martijn Adelmund hoopt, zoals gezegd, "dat scholieren dit boek lezen naast het origineel en nadenken over ons koloniale verleden en wat de gevolgen daarvan zijn in het heden" (Z: 303). Hij geeft daartoe ook lezingen in scholen, heeft een lesbrief gemaakt en zijn roman voorzien van een annex met tabellen waarin precies aangegeven wordt welke stukken uit Couperus en Multatuli waar terechtgekomen zijn in Zombieland. Overigens heeft hij, om zijn werk nog appetijtelijker te maken voor het jonge publiek, gemanipuleerde foto's opgenomen van Javanen wier hoofd vervangen is door een doodskop of wier darmen uit hun buik bengelen. Het is wel jammer dat het boek zo vreselijk slecht ingebonden is. Mijn exemplaar hangt al helemaal uit elkaar.

Het doel van Adelmund is nobel. Over de vraag of hij het juiste middel heeft gekozen, kan men van mening verschillen. Net als over de vraag of het überhaupt een goed idee is om meesterwerken te hertalen en te bewerken. Maar over één zaak valt niet te discussiëren: vakmanschap. Dan gelden niet de meningen, maar de feiten.

\section{Bibliografie}

Couperus, Louis. 1900. De stille kracht. Twee delen. Amsterdam: Veen. 1987-1996. Volledige werken. Amsterdam/Antwerpen: Veen.

Multatuli. 1992. Max Havelaar of de koffiveilingen der Nederlandsche Handelmaatschappy. Historisch-kritische uitgave, verzorgd door A. Kets-Vree. Deel 1: Tekst. Deel 2: Apparaat en commentaar. Assen/Maastricht: Van Gorcum. (Monumenta Literaria Neerlandica VI, 1 en 2). 
2014. Max Havelaar of de koffieveilingen van de Nederlandse handelmaatschapppij. Hertaald en bewerkt door Gijsbert van Es. 8 ed. Amsterdam: Nieuw Amsterdam NRC Boeken.

2016. Max Havelaar met zombies. Hertaald en bewerkt door Martijn Adelmund. Amsterdam: Luitingh-Sijthoff

Vermoortel, Philip. 2016. “Aan de barbaren de eindzege?” Werkwinkel 11(1): 29-40. 